\title{
Effects of COVID-19 Outbreak on Emergency Surgeries for Occlusive Colorectal Cancers
}

\section{COVID-19 Salgınının Acil Cerrahide Tıkayıcı Kolorektal Kanser Ameliyatları Üzerindeki Etkileri}

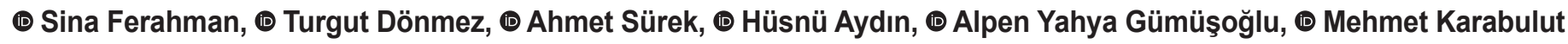 \\ Bakırköy Dr. Sadi Konuk Training and Research Hospital, Clinic of General Surgery, İstanbul, Turkey
}

\section{IIIIIIII| ABSTRACT}

Aim: Coronavirus-19 (COVID-19) is caused by severe acute respiratory syndrome-coronavirus 2 (SARS-CoV-2). Since the CoV-19 outbreak, public health has been affected in several areas, especially, mortality from malignancies has increased. Colorectal cancers (CRCs) is the third-most common cause of cancer-related deaths across the world. The present study aimed to investigate the time of CRC patients' admission to hospital and its effects in the light of COVID-19 outbreak.

Method: We examined the case of 62 patients who visited our hospital emergency department with intestinal obstruction due to CRC between 2019 and 2020. We categorised the patients admitted during the COVID-19 pandemic as group 1 and the others as group 2. We comparatively evaluated the demographic data, complaints and duration, tumour characteristics, blood values, complications, mortality rates and the length of hospital stay of the patients. We noted that the duration of admission to the hospital was prolonged after the patients developed obstructive symptoms.

Results: As incidences of nausea/vomiting became more frequent, the duration of admission to the hospital after the complaints began and the resultant mortality rate were statistically higher among the group 1 patients. The haematocrit (htc) value was lower and the tumour size was larger in the deceased patients.

Conclusion: COVID-19 pandemic delayed the diagnosis of patients with colorectal cancer. The time that elapsed after occlusion in CRC increased the rate of mortality and morbidity. It was observed that, especially, mortality was higher for elderly patients with low htc values. This increase in the mortality rates suggests the importance of the time of admission to the hospital in case of obstructive CRC. We thus believe that it is essential to propagate that the hospitals are safe from COVID to encourage the public to avail hospital services for serious cases in order to ensure timely diagnosis and treatment.

Keywords: Colorectal cancer, COVID-19, mortality, occlusion

\section{|||||||||| ÖZ}

Amaç: Koronavirüs-19 (COVID-19), şiddetli akut solunum sendromu-koronavirüs 2'den (SARS-CoV-2) kaynaklanır. COVID-19 salgını sırasıda, çeşitli alanlarda halk sağlığı etkilenmiş, özellikle malignitelerden ölüm oranları artmıştır. Kolorektal kanserler (CRC), dünya çapında kansere bağlı ölümlerin üçüncü en yaygın nedenidir. Bu çalışma, CRC hastalarının hastaneye yatış sürelerini ve etkilerini COVID-19 salgını etkisinde incelemeyi amaçlamaktadır.

Yöntem: 2019-2020 yılları arasında CRC’ye bağlı bağırsak tıkanıklığı nedeniyle hastanemiz acil servisimize gelen 62 hastayı inceledik. COVID-19 salgını sırasında başvuran hastaları grup 1 ve diğerlerini grup 2 olarak kategorize ettik. Hastaların demografik verilerini, şikayet ve süresini, tümör özelliklerini, kan değerlerini, komplikasyonlarını, ölüm oranlarını ve hastanede kalış sürelerini karşılaştırdık. Hastalarda obstrüktif semptomlar geliştikten sonra hastaneye başvuru süresinin uzadığını belirledik.

Bulgular: Bulantı/kusma sıklığı arttıkça, şikayetler başladıktan sonra hastaneye başvuru süresi ve sonuçta ortaya çıkan ölüm oranı grup 1 hastalarında istatistiksel olarak daha yüksek bulundu. Ölen hastalarda hematokrit (Htc) değeri daha düşüktü ve tümör boyutu daha büyüktü.

Sonuç: COVID-19 salgını, kolorektal kanserli hastaların teşhisini geciktirdi. CRC'de oklüzyondan sonra geçen süre mortalite ve morbidite oranını artırdı. Özellikle Htc değeri düşük yaşlı hastalarda mortalitenin daha yüksek olduğu görüldü. Ölüm oranlarındaki bu artış, obstrüktif CRC durumunda hastaneye yatış süresinin önemini ortaya koymaktadır. Bu nedenle, zamanında tanı ve tedaviyi sağlamak için halkı ciddi olgularda hastane hizmetlerinden yararlanmaya teşvik etmenin gerekli olduğuna inanıoruz.

Anahtar Kelimeler: Kolorektal kanser, COVID-19, mortalite, tıkanma

Address for Correspondence/Yazışma Adresi: Sina Ferahman, MD,

Bakırköy Dr. Sadi Konuk Training and Research Hospital, Clinic of General Surgery, İstanbul, Turkey

E-mail: sinaferahmantr@hotmail.com ORCID ID: orcid.org/0000-0003-1160-9156

Received/Geliş Tarihi: 01.07.2020 Accepted/Kabul Tarihi: 20.07.2020

${ }^{\circ}$ Copyright 2020 by Turkish Society of Colon and Rectal Surgery

Turkish Journal of Colorectal Disease published by Galenos Publishing House. 


\section{Introduction}

The 2019 novel coronavirus disease-19 (COVID-19) originated in Wuhan, China in December 2019. COVID-19 is caused by severe acute respiratory syndrome-coronavirus 2 (SARS-CoV-2). ${ }^{1}$ On 11 March 2020, the first COVID-19 patient was reported in Turkey. Since then, major hospitals across the country were rapidly transformed into pandemic care centres. ${ }^{2}$ The intensive care units of the hospitals began to prioritise COVID-19 cases. Some hospitals' operating rooms were converted into special intensive care units. All physicians, irrespective of their expertise, were involved in the treatment of COVID-19 patients during the pandemic period. Hospitals had restricted their services other than emergency services and treatment for cancer patients. ${ }^{3}$ This process continued until the normalisation began on 1 June 2020. Since then, the closed outpatient clinics have reopened, and doctors have returned to care for patients in their respective clinics and care centres. Between 11 March and 1 June 2020, the public was notified by the government to not go outside unless necessary. People aged $>65$ and $<18$ years were banned from strolling on the streets. A nationwide curfew was declared by the government on weekend days., ${ }^{2,4}$ Considering these prohibitions and adaptations, patients with any medical conditions were hesitant to visit a hospital, which delayed their diagnosis. ${ }^{5}$

Our hospital is a tertiary state hospital and a level 1 trauma centre that serves as a training hospital. Every year, $>100$ patients are operated here for occlusive colorectal cancers (CRCs) in our hospital's emergency surgery department. ${ }^{6}$

CRC is the third-most common cause of cancer-related death worldwide, taking into account $>1$ million new cancer diagnoses and 600,000 cancer deaths every year. ${ }^{7}$ The incidence of cancer in Turkey is not different from that in the world. CRC is the fourth-most common malignancy affecting both the sexes. ${ }^{8}$ Patients can be diagnosed with cancer with incidental or community scans (e.g. colonoscopy, hidden stool blood, etc.). However, in the emergency departments, complaints such as abdominal pain, intestinal obstruction, bloating, increased body temperature and significant weight loss can be diagnosed. Unfortunately, gastrointestinal symptoms are not specific, which often causes a delay in the presentation of the patient as well as misdiagnosis, consequently delaying the CRC diagnosis. About one-third of the CRC patients showed delayed seeking of medical advice and treatment. In addition, approximately half of the patients were affected by this delay in their cancer diagnosis. In the absence of adequate screening programmes or health promotion programmes for the CRC, $93.7 \%$ of the cases were expected to be diagnosed after symptomatic presentation.
In CRC, the incidence of surgery in the emergency room is approximately $15 \%$ with the initial diagnosis., ${ }^{9,10,11}$

The gold-standard method for CRC screening is colonoscopy as it has high sensitivity, especially for the detection and removal of precancerous lesions. ${ }^{12}$ According to the US Preventive Services Task Force, colonoscopy can detect CRC and precancerous lesions in adults of ages $50-75$ years at an early stage. ${ }^{13}$ Colonoscopy may be performed at an earlier age, especially in individuals with a familial predisposition. ${ }^{12}$ During the covid-19 epidemic, the numbers of non-emergency endoscopy procedures performed were reduced based on the recommendations of relevant associations and literatures. ${ }^{14,15,16}$ This reduced numbers of colonoscopies delayed the treatment of newly detectable CRCs. Early diagnosis of CRC can decrease the mortality and morbidity rates of patients as well as increase their 5 -year survival rates. ${ }^{17}$

Regarding delay in the presentation of symptoms, abdominal distension has the longest mean duration, followed by rectal pain. Rectal pain had the longest median duration of 180 days, followed by diarrhoea (median duration $=150$ days). ${ }^{18,19}$ In addition, other symptoms such as weight loss, anaemia, stool occult blood, weakness and change in the defecation routine has been reported. Severe abdominal pain, nausea/ vomiting and bloating in the abdomen have been reported, especially after full occlusion of the colon by tumour. ${ }^{20}$

Because of the rapid spread of COVID-19, hospitals all across the world have become an important source of transmission. ${ }^{21}$ This fast spread of infection has made people paranoid about visiting a hospital. People aged $>65$ years, in particular, with the effect of the curfew, refused to visit hospitals even when faced with ailments. , $22^{2}$

The aim of the present study was to examine patients with colorectal occlusion tumours who delayed coming to the hospital during the COVID-19 outbreak. Apart from the primary outcomes of the COVID-19 outbreak, it is important to specifically investigate the effect on patients with pre-existing malignancy. Early admission to the hospital is therefore considered to improve the mortality and morbidity of patients with occlusive CRC.

\section{Materials and Methods}

This is a retrospective study. The study was approved by the local ethics committee and the Ministry of Health Scientific Research Institution (Ref. No: 2020-06-16T14_25_40). Patients who underwent emergency surgeries between March and June 2020 and between March and June 2019 were examined. In the study patients, the tumour mass was confirmed by computed tomography using oral, rectal and intravenous contrast in the colorectal region. In some of 
the study patients, the tumour mass caused obstruction in the colorectal region and they were accordingly stented or operated. Patients who were admitted in the year 2020 were categorised in group 1 and those admitted in the year 2019 were categorised in group 2 .

Patients under the age of 18 years and who did not have obstruction, bowel-wide dilatation, routine defecation, stent, neoadjuvant chemotherapy, benign causes and recurrence were excluded from the study.

Thorax CT was performed in all patients of group 1 before their surgery. Polymerase chain reaction (PCR) was performed for patients suspected of COVID-19. Patients with COVID-19 findings in Thorax CT or PCR were considered to be COVID-19 positive.

Stent attachment was attempted in obstructive CRC patients with colonoscopy. In case of a suspicion of perforation or a high degree of dilatation of the bowel diameter on $\mathrm{CT}$, the patient was operated. Oncological surgery was performed for patients without metastasis in the abdomen and with a resectable tumour. Advanced-stage tumour was opened to diverting stoma in hemodynamically unstable patients. All anastomoses were prepared using staples. Linear staples were preferred as $70 \mathrm{~mm}$ or $100 \mathrm{~mm}$ and circular staples were preferred as $31 \mathrm{~mm}$.

The data on age, gender, presence of comorbidity, the American Society of Anaestology score, body mass index (BMI), colonoscopy outcomes, complaint time, stent status, operation time, need for intensive care unit, complication, white blood cells (WBC), neutrophil count, haematocrit value, C-reactive protein (CRP), the location of the tumour, tumour size, histopathological type, hospitalisation time and mortality were transferred to the computer system. The comorbidities of the patients were graded based on the Charlson comorbidity index. Groups 1 and 2 patients were compared statistically with each other.

Group 1 patients were separated according to mortality rate in order to examine the causes of death in further detail. The data of the deceased patients were compared with those of other patients.

All procedures performed in this study involving human participants were performed in accordance with the 1964 Helsinki Declaration and its later amendments or with comparable ethical standards. Informed consent was obtained from all individual participants included in the study. The authors declare no competing financial interests and no conflict of interests.

\section{Statistical Analysis}

Statistical analysis was performed with $\mathrm{JMP}^{\circledR}$ software version 10.0.0 (SAS ${ }^{\circledast}$ Institute, Inc., Cary, North Carolina,
USA). Patient characteristics were analysed via descriptive statistics. For continuous variables, the mean and standard derivation or the median and interquartile ranges were calculated. For categorical variables, the numbers and percentages were recorded for each category. Differences between the parameters were compared with Mann-Whitney $\mathrm{U}$ test. Categorical variables were compared by chi-square test. $\mathrm{P} \leq 0.05$ were accepted to be statistically significant.

\section{Results}

A total of 62 patients admitted between March-June 2020 and March-June 2019 were compared. Group 1 consisted of 35 patients and group 2 consisted of 27 patients. Of all, 23 (37.1\%) of the patients were women and $39(62.9 \%)$ were men. The mean age of the patients was $63( \pm 12.13)$ years and their mean BMI was $26.5( \pm 5.7)$. According to the Charlson comorbidity index, the mean value of group 1 patients was $6.9( \pm 2.45)$, while that of group 2 patients was $7.1( \pm 2.68)$.

When the tumour's location in the colon was evaluated, the most common malignancy was recorded in the rectosigmoid region, followed by hepatic flexor tumours. Histopathologically, adenocarcinoma was the most common type detected (Table 1).

When the patients' complaints were studied, abdominal pain and nausea/vomiting were observed to be most frequent. Abdominal swelling and rectal bleeding were among the additional complaints. The average duration of complaints in group 1 was $8.9( \pm 4.97)$ days, while this period was 2.3 $( \pm 1.46)$ days in group 2. Stent attachment was attempted in 26 patients via colonoscopically. The stent could not be inserted in 6 patients due to the complete blockage of the lumen by the tumour or due to technical incompetence. These patients underwent operation. Two patients were operated after successful stent placement because of insufficient defecation (Table 1).

Examination of the preoperative blood results revealed the mean WBC count of $11.900( \pm 5.21) / \mu \mathrm{L}$, the average neutrophil count of $9.6( \pm 5.09) / \mu \mathrm{L}$, the mean haematocrit value of $37( \pm 7.11)$ and the average CRP value of 102.8 $( \pm 108.23) \mathrm{mg} / \mathrm{L}$. In all, $5(14.3 \%)$ patients were diagnosed with COVID-19 by thorax CT imaging and/or PCR (Table 2).

A total of 44 patients were operated for occlusive CRC. During the operation, 7 patients with metastases in the abdomen were exposed to the stoma and 37 patients were operated under surgical oncology techniques. All surgeries were performed by using open techniques. The mean operation time was $169.1( \pm 50.21) \mathrm{min}$, and $12(34.3 \%)$ patients in group 1 and 10 (37\%) patients in group 2 required intensive care unit (ICU). During the follow-up of the patients, evisceration was recorded in 4 (6.5\%) patients, 
anastomotic leak in $2(3.2 \%)$ and bleeding in 1 (1.6\%). These patients were operated for the second time. Stoma was opened to patients with anastomosis leak. Intra-abdominal abscess was noted in 2 (3.2\%) patients. A drain was installed via interventional radiology (Table 3).

The pathological examination revealed the average tumour size of $5.4( \pm 1.46) \mathrm{cm}$ and $4.3( \pm 0.99) \mathrm{cm}$ for groups 1 and 2, respectively. According to the Union for International Cancer Control, based on the tumour-node-metastasis
(TNM) staging system, 16 patients were classified as T3, 20 as T4, 9 as N0, 16 as N1 and 9 as N2 (Table 4).

The patients were followed up on an average for $8.3( \pm 7.02)$ days in the hospital. Eleven patients died (17.7\%): 9 (25.7\%) from group 1 and 2 (7.41\%) from group 2.

The patients in group 1 were separated according to their mortality status and their results were compared. The mean age of the patients who died was $69( \pm 5.94)$ years, mean BMI was $27.6( \pm 7.62)$ and mean Charlson comorbidity

Table 1. Group 1 patients presented with occlusive colon for colorectal cancer during COVID-19 outbreak. Group 2 patients applied for the same period of 2019. The demographic data, tumour locations, blood values and colonoscopy stent conditions are depicted

\begin{tabular}{|c|c|c|c|c|}
\hline & Group $1(2020 n=35)$ & Group $2(2019 n=27)$ & Total $(n=55)$ & $\mathrm{p}$ \\
\hline \multicolumn{5}{|l|}{ Gender } \\
\hline Female & $13(37.1 \%)$ & $10(37 \%)$ & $23(37.1 \%)$ & \multirow[t]{2}{*}{0.993} \\
\hline Male & $22(62.9 \%)$ & $17(63 \%)$ & $39(62.9 \%)$ & \\
\hline Age & $61.3( \pm 10.86)$ & $65.3( \pm 13.48)$ & $63( \pm 12.13)$ & 0.164 \\
\hline \multicolumn{5}{|l|}{ ASA $^{*}$} \\
\hline II & $7(20 \%)$ & $4(14.8 \%)$ & $11(17.7 \%)$ & \multirow{3}{*}{0.860} \\
\hline III & $24(68.6 \%)$ & $20(74.1 \%)$ & $44(71 \%)$ & \\
\hline IV & $4(11.4 \%)$ & $3(11.1 \%)$ & $7(11.3 \%)$ & \\
\hline $\mathrm{BMI}^{* *}$ & $26.9( \pm 5.88)$ & $25.9( \pm 5.53)$ & $26.5( \pm 5.7)$ & 0.268 \\
\hline Charlson comorbidity index & $6.9( \pm 2.45)$ & $7.1( \pm 2.68)$ & $7( \pm 2.54)$ & 0.931 \\
\hline \multicolumn{5}{|l|}{ Tumour localisation } \\
\hline & $1(2.9 \%)$ & $3(11.1 \%)$ & $4(6.5 \%)$ & \multirow{9}{*}{0.431} \\
\hline Cecum & $1(2.9 \%)$ & $3(11.1 \%)$ & $4(6.5 \%)$ & \\
\hline Right colon & $7(20 \%)$ & $3(11.1 \%)$ & $10(16.1 \%)$ & \\
\hline $\begin{array}{l}\text { Hepatic flexura } \\
\text { Transverse colon }\end{array}$ & $2(5.7 \%)$ & $0(0 \%)$ & $2(3.2 \%)$ & \\
\hline Splenic flexura & $1(2.9 \%)$ & $1(3.7 \%)$ & $2(3.2 \%)$ & \\
\hline Left colon & $2(5.7 \%)$ & $1(3.7 \%)$ & $3(4.8 \%)$ & \\
\hline $\begin{array}{l}\text { Sigmoid } \\
\text { Recto-sigmoid }\end{array}$ & $9(\% 25.7)$ & $10(\% 38.4)$ & $19(30.6 \%)$ & \\
\hline \multirow[t]{2}{*}{ Rectum } & $7(20 \%)$ & $4(15.4 \%)$ & $11(17.7 \%)$ & \\
\hline & $5(\% 14.3)$ & $2(7.7 \%)$ & $7(11.3 \%)$ & \\
\hline \multicolumn{5}{|l|}{ Blood } \\
\hline $\mathrm{WBC} \dagger$ & $12.4( \pm 5.39)$ & $11.3( \pm 5.02)$ & $11.9( \pm 5.21)$ & 0.281 \\
\hline Neutrophils & $10.3( \pm 5.19)$ & $8.6( \pm 4.9)$ & $9.6( \pm 5.09)$ & 0.142 \\
\hline HTC $\neq$ & $38.6( \pm 7.1)$ & $35.1( \pm 6.75)$ & $37( \pm 7.11)$ & 0.120 \\
\hline $\mathrm{CRP} \dagger \dagger$ & $107.6( \pm 121.27)$ & $96.6( \pm 90.43)$ & $102.8( \pm 108.23)$ & 0.837 \\
\hline \multicolumn{5}{|l|}{ Stent insertion } \\
\hline Successful & $11(31.4 \%)$ & $9(33.3 \%)$ & $20(32.3 \%)$ & \multirow{2}{*}{0.335} \\
\hline Fail & $5(14.3 \%)$ & $1(3.7 \%)$ & $6(9.7 \%)$ & \\
\hline
\end{tabular}

*ASA: American Society of Anestology, ${ }^{* * B M I}$ : Body mass index, †WBC: White blood cell, $¥ \mathrm{HTC}$ : Haematocrit, ††CRP: C-reactive protein, COVID-19: Coronavirus disease-19 
index was $8.2( \pm 2.49)$. The most common tumour was recorded in the hepatic flexure and the rectum. The mean CRP value was $133.8( \pm 144.87) \mathrm{mg} / \mathrm{L}$. On the other hand, the colonoscopy procedure was performed in 2 patients, and a stent was inserted in 1 patient. All patients required ICU after the surgery. They were all admitted to the hospital most frequently for abdominal pain and nausea/vomiting. The average duration of the complaints was 13.1 $( \pm 4.57)$ days. The results of the tests revealed that 1 patient was COVID-19 positive. The average length of stay in the hospital was $8.2( \pm 8.29)$ days (Tables 3 and 4$)$.
The patients who were divided into group 1 and group 2 were compared based on their gender, age, ASA score, Charlson comorbidity index, localisation of the tumour, blood values, surgical technique, duration of surgery and the need for ICU. No statistically significant difference was noted between the groups (Table 1).

The time lapse since the patients' complaints and admission to the hospital was significantly longer in group 1 than in group 2 ( $<<0.001)$. Moreover, the mortality rate was statistically significantly higher of group 1 than of group 2 $(p=0.036)$. Especially, the complaints of nausea/vomiting

Table 2. During the operation, stomata was applied to metastatic patients who were at the advanced disease stage. The other patient was operated as per the oncological principles. Intensive care (ICU) needs. complications. complaints and admission times, tumour sizes and the disease stages of the patients are shown. Presence of COVID-19 infections were evaluated

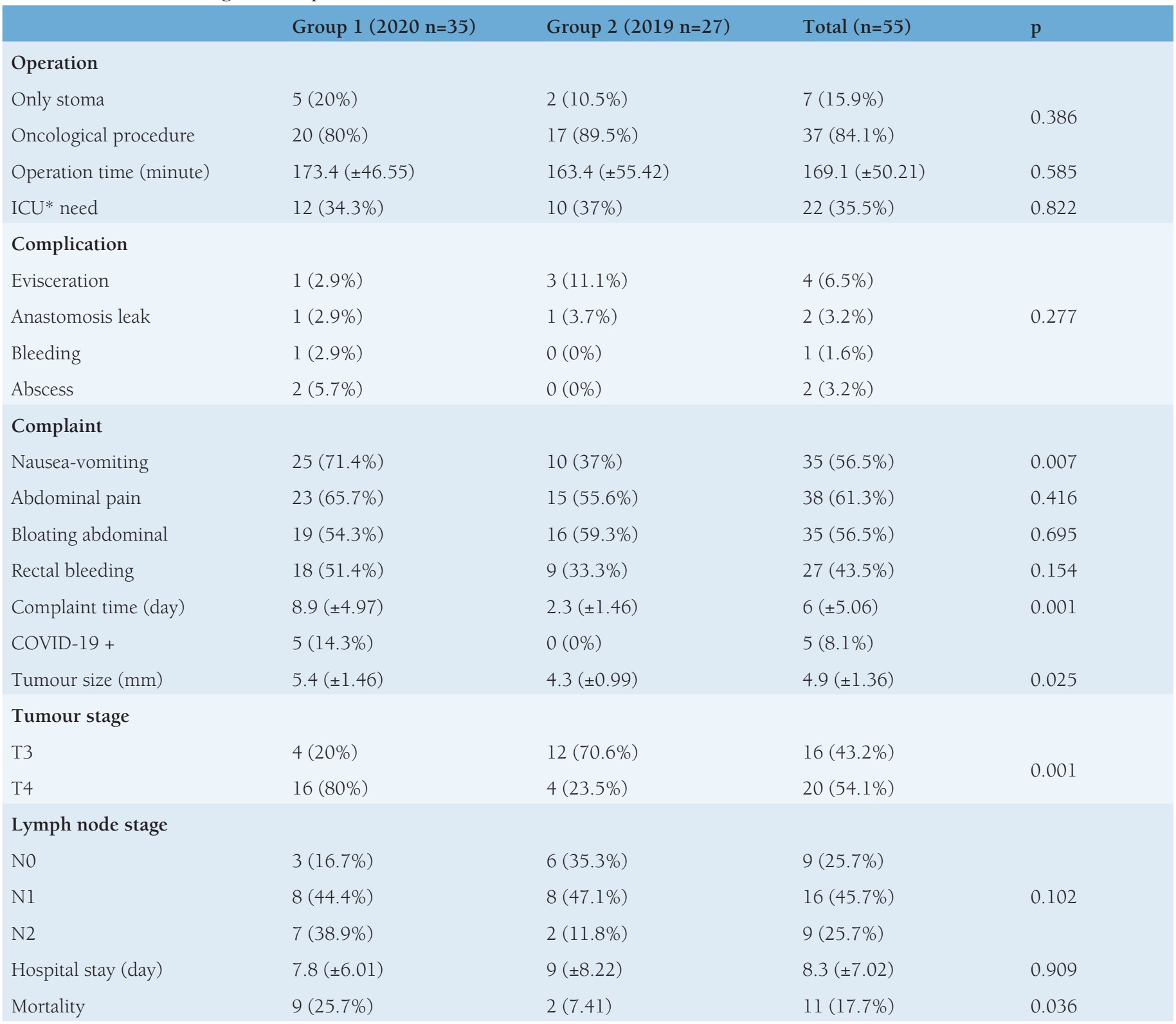

*ICU: Intensive care unit 
were more frequently recorded for group 1 ( $\mathrm{p}=0.007)$. Tumour sizes were statistically significantly larger among group 1 patients $(\mathrm{p}=0.025)$. In TNM staging, T4 tumours were statistically more common in group 1 than in group 2 ( $\mathrm{p}=0.009)$ (Table 2).

Group 1 patients were divided in accordance with their mortality status. The details of the deceased patients and others are compared in Tables 3 and 4. Age and the complaint duration was significantly longer among the deceased patients. Notably, all patients required intensive care after the surgery. The htc values of the deceased patients were statistically lower than those of other patients $(p=0.005)$.

\section{Discussion}

Past studies in the literature had evaluated the time between the first complaint and the surgery. Several studies have demonstrated that prolonging this period reduces the overall 5 -year survival. ${ }^{23,24}$ In some studies, when the first symptom

Table 3. Patients who were admitted during the COVID-19 outbreak were categorised based on their mortality status. The demographic data. tumour locations, blood values and colonoscopic stent conditions are shown

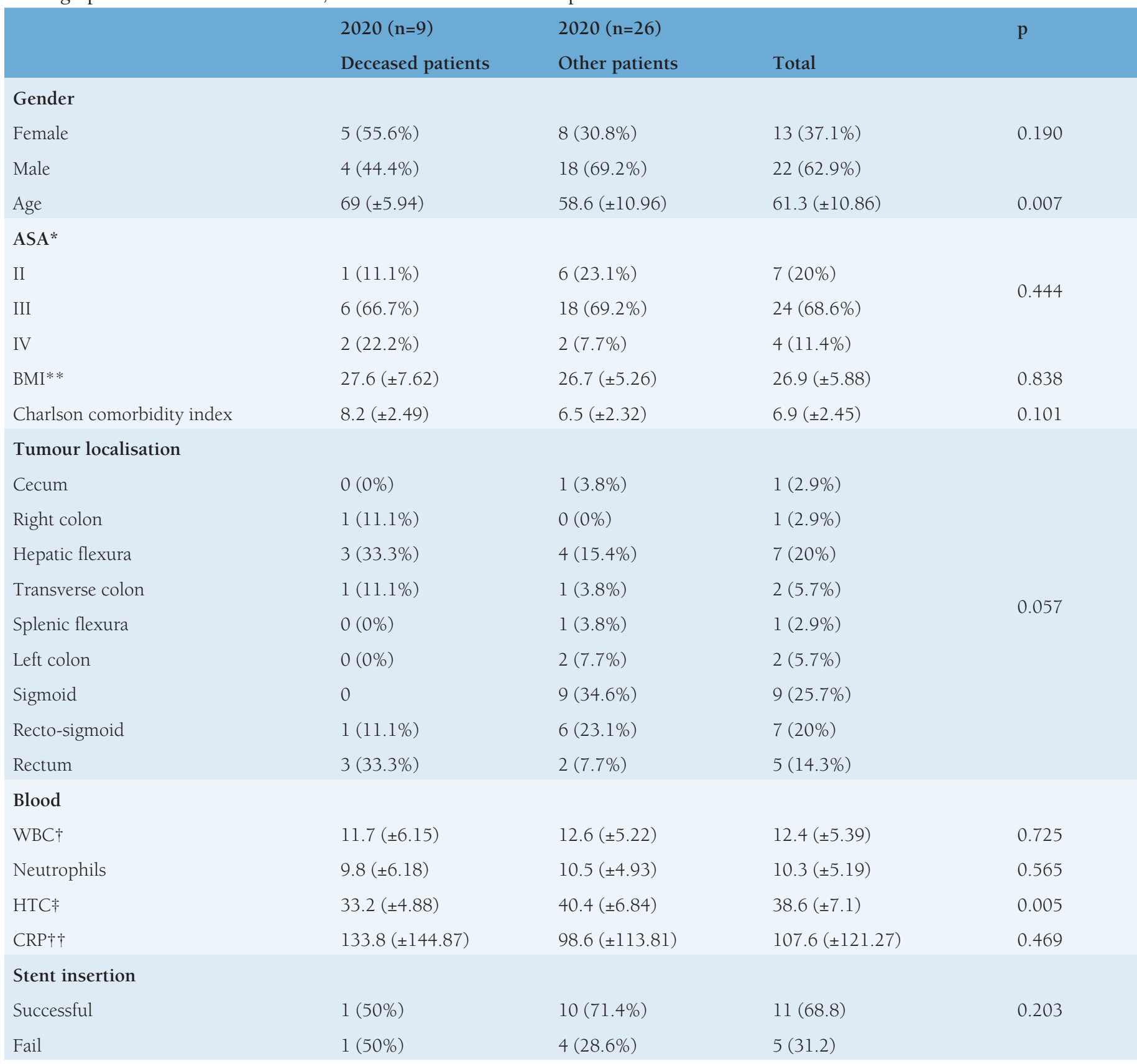

*ASA: American Society of Anestology, **BMI: Body mass index, †WBC: White blood cell, $¥$ HTC: Haematocrit, $\uparrow \dagger C R P$ : C-reactive protein 
was noted, the duration of the first consultation to the doctor and the duration until the surgery were examined, and the prolongation of this period was found to affect the patients negatively. The difference between our study from those in the literature is that CRC patients evaluated the time after the development of occlusion symptoms. After the tumour clogged the intestines, we evaluated the duration of abdominal pain, nausea/vomiting, bloating and rectal bleeding among the patients.

CRC is predominantly a disease of the elderly and an important cause of morbidity and mortality in the population. It is the third-most common cancer in the world, but the most common malignant disease among the elderly. ${ }^{25}$ In addition to being common, CRC is a condition that can potentially be improved by surgery. CRCs should be managed as early as possible to prevent occurrence of late complications, such as congestion and perforation, via surgical resection of the primary tumour. ${ }^{17,26}$ As mentioned in several past studies, the primary reason for delaying diagnosis in CRC is the delay in the patients' consultation with a doctor for their complaints. It is an important reason for its attachment to haemorrhoids without investigation, especially for rectal bleeding. The doctors' approach to their patients, their way of listening, and detailed questioning

Table 4. The factors of mortality intensive care (ICU) needs complications complaints and admission times tumour sizes and stages of the patients are shown. The presence of COVID-19 infections were evaluated

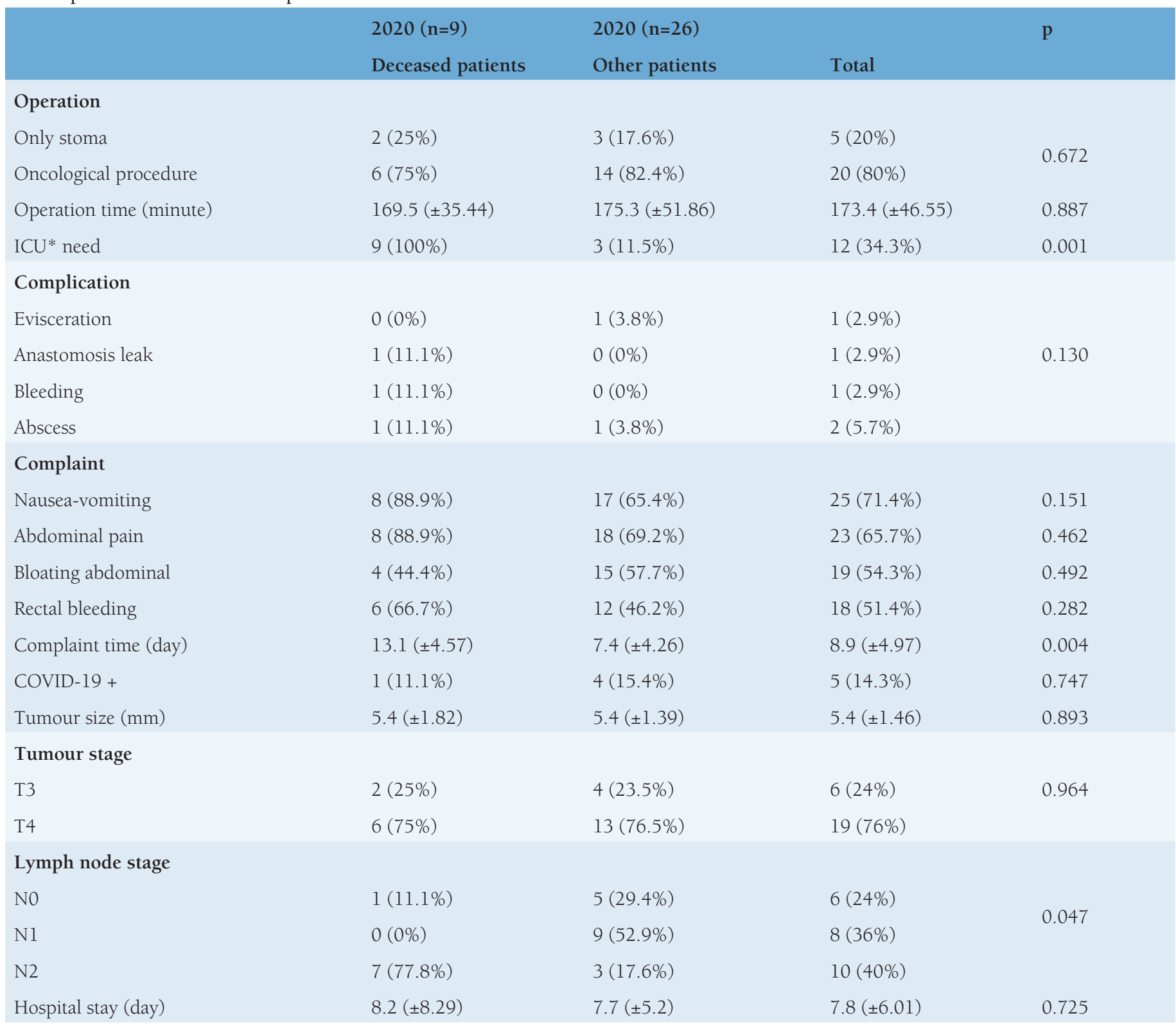

*ICU: Intensive care unit 
are important to reveal the complaints of the patients. Attempting to treat the issue without proper investigation can cause iron deficiency (anaemia), which is among the known causes of delay. ${ }^{27,28,29,30}$

The treatment processes of patients diagnosed with CRC prior to the COVID-19 outbreak could be configured accordingly. CRC patients diagnosed during this period were directed to neoadjuvant chemotherapy or operated based on the recommendations. Since the patients with symptoms are aware of the seriousness of their own condition, they visit the hospital early and are operated electively. ${ }^{31}$ This process was more complicated for patients who were unaware of any suspicious lesion in the colorectal area before the pandemic with colonoscopy or radiological imaging.

Mounce et al. ${ }^{32}$ examined 4,512 patients with delayed CRC. In CRC, a diagnosis period of 9-32 days is reasonable, and any further delay in diagnosis increases the mortality and morbidity rates of the patients. ${ }^{32}$ Survival depends on the stage of diagnosis, For instance, the 5-year survival is $90 \%$ for early cancers (Dukes A), whereas it is $15 \%$ for advanced tumours, where only palliative resection is possible..$^{33}$ However, studies on the examination of the time to admit to a hospital after the manifestations of the complaints in patients with advanced CRC are very rare. During the COVID-19 outbreak, especially, elderly patients preferred not to visit a hospital due to the curfew imposed on individuals aged $>65$ years and for the fear of hospitalacquired infections. ${ }^{5}$ While the average time to hospital admission was $2.3( \pm 1.46)$ days after the complaints of patients started in 2019, this period was extended to 8.9 $( \pm 4.97)$ days during the pandemic period. For patients who lost their lives, this period was $13.1( \pm 4.57)$ days.

It is known that CRC cancers are the most common ones in the recto-sigmoid region. In delayed CRC, the most common tumours are recorded in the cecum and right colon. In our study, tumour placement of patients was most frequently in the recto-sigmoid region. Although these patients had serious complaints, they did not prefer to go to the hospital. When the complaints of the patients to be admitted to the hospital were examined, the most common complaints were nausea and vomiting in group 1 patients. Abdominal bloating and pain were more common in group 2 patients. However, the common complaint was rectal bleeding. In a study by Tomlinson et al. ${ }^{34}$, patients with complaints since $>1$ month and $<1$ month were compared to reveal that the most common complaints were abdominal pain and rectal bleeding. Although we recorded similar outcomes from the literature, the fact that nausea and vomiting are more common can be explained by the fact that patients delay their arrival to the hospital after the occurrence of complete occlusion. One of the most important reasons for the prolongation of this process may be that the public does not have sufficient information about CRCs.

\section{Conclusion}

In conclusion, COVID-19 pandemic delayed the diagnosis of patients with CRC. The number of elective colonoscopies and surgeries performed were relatively less during these 3 months of lockdown. Accordingly, the time to admit patients to the hospital was extended. Patients preferred not to visit the hospital until their complaints worsened. The time elapsed after occlusion in advanced CRCs increased the subsequent complications and chances of morbidity. It was observed that, especially, mortality was higher for elderly patients with low htc value. This increase in the mortality rate suggests the importance of the time to admit to the hospital in case of obstructive CRC. The inconveniences caused due to the COVID-19 outbreak are innumerable. Unless treated at hospitals, the state of these patients cannot be normalised. Especially, during this period, when all healthcare professionals examined the patients in more detail than normal, they may compensate for the time lost during the pandemic period. Notably, patients who presented with nausea/vomiting complaints are considered to be at higher risk. Promoting that hospitals are safe from COVID-19 infection will ensure that the public, especially individuals who are afraid to go to the hospital out of their COVID-19 infection fear, can easily reach the hospitals when required. It may be an option to distinguish our hospitals as COVID-19 infected and non-infected. Moreover, we noted that the complaints of patients are also difficult to monitor. It is not easy to determine which complaint should be given immediate attention and which complaint can be managed at home. Governmental and non-governmental organisations may require long-term training for their staff on this point. We believe that, this way, we can prepare ready-made health institutions for more efficient management in case of any future pandemic scenario.

\section{Ethics}

Ethics Committee Approval: The study was approved by the local ethics committee and the Ministry of Health Scientific Research Institution (Ref. No: 2020-06-16T14_25_40).

Informed Consent: Informed consent was obtained from all individual participants included in the study.

Peer-review: Internally peer reviewed.

\section{Authorship Contributions}

Surgical and Medical Practices: S.F., T.D., A.S., H.A., A.Y.G., M.K., Concept: S.F., T.D., Design: T.D., Data Collection or Processing: A.S., H.A., Analysis or Interpretation: M.K., Literature Search: A.S., H.A., Writing: S.F. 


\section{Conflict of Interest: No conflict of interest was declared by the authors. \\ Financial Disclosure: The authors declared that this study received no financial support.}

\section{References}

1. Zhou F, Yu T, Du R, Fan G, Liu Y, Liu Z, Xiang J, Wang Y, Song B, Gu $\mathrm{X}$. Clinical course and risk factors for mortality of adult inpatients with COVID-19 in Wuhan, China: a retrospective cohort study. Lancet 2020. doi: 10.1016/S0140-6736(20)30566-3

2. Demirbilek Y, Pehlivantürk G, Özgüler ZÖ, MEŞE EA. COVID-19 outbreak control, example of ministry of health of Turkey. Turk J Med Sci 2020;50:489-494.

3. Ögütlü H. Turkey's response to COVID-19 in terms of mental health. Ir J Psychol Med 2020:1-11.

4. Dergiades T, Milas C, Panagiotidis T. Effectiveness of Government Policies in Response to the COVID-19 Outbreak, 2020. doi: 10.2139/ssrn.3602004

5. Ferahman S, Aydin H, Sahbaz NA, Akarsu C, Peker KD, Donmez T, Karabulut M. Analysis of general surgery outpatient clinic admissions and operations during COVID-19 pandemic in Turkey: Reactions of 12728 patients. Bratisl Med J 2020;7:475-480

6. The first 100-hospitals in each branch in connection with the outpatient clinic hospital and intensive care unit and emergency room data, 2017. Available from: https://dosyahastane.saglik.gov.tr/Eklenti/9300,2017ocak-ekim-donemi-poliklinik-yatis-ve-yogun-bakim-ve-acil-servisverileri-baglaminda-her-bransta-ilk-100-hastanepdf.pdf?0

7. Ferlay J, Soerjomataram I, Dikshit R, Eser S, Mathers C, Rebelo M, Parkin DM, Forman D, Bray F. Cancer incidence and mortality worldwide: sources, methods and major patterns in GLOBOCAN 2012. Int J Cancer 2015;136:E359-E386.

8. Tatar M, Tatar F. Colorectal cancer in Turkey: current situation and challenges for the future. Eur J Health Eco 2010;10(Suppl 1):S99-105.

9. Vickers NJ. Animal communication: when i'm calling you, will you answer too? Current Biol 2017;27:R713-R715.

10. Tørring ML, Frydenberg M, Hansen RP, Olesen F, Hamilton W, Vedsted $\mathrm{P}$. Time to diagnosis and mortality in colorectal cancer: a cohort study in primary care. Br J Cancer 2011;104:934-940.

11. Smothers L, Hynan L, Fleming J, Turnage R, Simmang C, Anthony T. Emergency surgery for colon carcinoma. Dis Colon Rectum 2003;46:2430.

12. Bauer A, Riemann JF, Seufferlein T, Reinshagen M, Hollerbach S, Haug $\mathrm{U}$, Unverzagt S, Boese S, Ritter-Herschbach M, Jahn P. Invitation to screening colonoscopy in the population at familial risk for colorectal cancer: a cluster-randomized study aimed at increasing participation rates. Deutsches Ärzteblatt Int 2018;115:715.

13. Stark UA, Frese T, Unverzagt S, Bauer A. What is the effectiveness of various invitation methods to a colonoscopy in the early detection and prevention of colorectal cancer? Protocol of a systematic review. Syst Rev 2020;9:1-7.

14. Chiu PWY, Ng SC, Inoue H, Reddy DN, Hu EL, Cho JY, Ho LK, Hewett DG, Chiu HM, Rerknimitr R. Practice of endoscopy during COVID-19 pandemic: position statements of the Asian Pacific Society for Digestive Endoscopy (APSDE-COVID statements). Gut 2020;69:991-996.

15. Thompson CC, Shen L, Lee LS. COVID-19 in endoscopy: Time to do more? Gastrointestinal Endoscopy 2020;92:435-439.

16. COVIDSurg Collaborative. Global guidance for surgical care during the COVID-19 pandemic. Br J Surg 2020;107:1097-1103.

17. Runkel N, Schlag P, Schwarz V, Herfarth C. Outcome after emergency surgery for cancer of the large intestine. Br J Surg 1991;78:183-188.
18. Abu-Helalah MA, Alshraideh HA, Abuseif A, Arqoob K, Ajaj A. Delay in presentation, diagnosis and treatment for colorectal cancer patients in Jordan. J Gastrointest Cancer 2016;47:36-46.

19. Pita-Fernández S, González-Sáez L, López-Calviño B, Seoane-Pillado T, Rodríguez-Camacho E, Pazos-Sierra A, González-Santamaría P, PértegaDíaz S. Effect of diagnostic delay on survival in patients with colorectal cancer: a retrospective cohort study. BMC Cancer 2016;16:664.

20. Arnaud J, Tuech J, Duplessis R, Pessaux P. Role of subtotal/total colectomy in emergency treatment of occlusive cancer of the left colon. Ann Chir 1999;53:1019-22.

21. Lenert L, McSwain BY. Balancing health privacy, health information exchange, and research in the context of the COVID-19 pandemic. J Am Med Inform Assoc 2020;27:963-966.

22. De Filippo O, D'Ascenzo F, Angelini F, Bocchino PP, Conrotto F, Saglietto A, Secco GG, Campo G, Gallone G, Verardi R, Gaido L, Iannaccone M, Galvani M, Ugo F, Barbero U, Infantino V, Olivotti L, Mennuni M, Gili S, Infusino S, Vercellino M, Zucchetti O, Casella G, Giammaria M, Boccuzzi G, Tolomeo P, Doronzo B, Senatore G, Marra WG, Rognoni A, Trabattoni D, Franchin L, Borin A, Bruno F, Galluzzo A, Gambino A, Nicolino A, Giachet AT, Sardella G, Fedele F, Monticone S, Montefusco A, Omedè P, Pennone M, Patti G, Mancone M, De Ferrari GM. Reduced rate of hospital admissions for ACS during Covid-19 outbreak in Northern Italy. N Eng J Med 2020;383:88-89.

23. Neal R, Din N, Hamilton W, Ukoumunne O, Carter B, Stapley S, Rubin G. Comparison of cancer diagnostic intervals before and after implementation of NICE guidelines: analysis of data from the UK General Practice Research Database. Br J Cancer 2014;110:584-592.

24. Ramos M, Esteva M, Cabeza E, Campillo C, Llobera J, Aguiló A. Relationship of diagnostic and therapeutic delay with survival in colorectal cancer: a review. Eur J Cancer 2007;43:2467-2478.

25. Harris G, Simson J. Causes of late diagnosis in cases of colorectal cancer seen in a district general hospital over a 2-year period. Ann R Coll 1998;80:246-248.

26. Phillips R, Hittinger R, Fry J, Fielding L. Malignant large bowel obstruction. Br J Surg 1985;72:296-302.

27. Hughes E, McDermott F, Masterton J. Delayed diagnosis of carcinoma of the rectum and sigmoid. ANZ J Surg 1979;49:432-433.

28. Goulston K, Cook I, Dent O. S.A.W.T.C. HOSPITAL, and G. UNIT, How important is rectal bleeding in the diagnosis of bowel cancer and polyps? Lancet 1986;328:261-265.

29. Goulston K, Dent O. Colorectal cancer. A plea for early diagnosis. Aust Fam Physician 1981;10:697-698.

30. Young CJ, Sweeney JL, Hunter A. Implications of delayed diagnosis in colorectal cancer. ANZ J Surg 2000;70:635-638.

31. Akyol C, Koç MA, Utkan G, Yıldız F, Kuzu MA. The COVID-19 pandemic and colorectal cancer: 5W1H-What should we do to whom, when, why and how. Turk J Colorectal Dis 2020;30:67-75.

32. Mounce LT, Price S, Valderas JM, Hamilton W. Comorbid conditions delay diagnosis of colorectal cancer: a cohort study using electronic primary care records. Br J Cancer 2017;11:1536-1543.

33. Mitchell E, Macdonald S, Campbell N, Weller D, Macleod U. Influences on pre-hospital delay in the diagnosis of colorectal cancer: a systematic review. Br J Cancer 2008;98:60-70.

34. Tomlinson C, Wong C, Au HJ, Schiller D. Factors associated with delays to medical assessment and diagnosis for patients with colorectal cancer. Can Fam Physician 2012;58:e495-e501. 